\title{
NETRALITAS POLRI DALAM PESTA \\ DEMOKRASI PEMILU PERSPEKTIF \\ PENDIDIKAN KEWARGANEGARAAN
}

Oleh: Tegub Soedarsono*

Abstract

This article focuses on the policy of netrality of Indonesian police in general election either in legislatives or executives election. Basically, the policy of netrality is a form of human rights violation in terms of democracy state. Through the policy, rights to vote as well as to be voted for Indonesian police is neglected. As a result, there is a democracy impair and not in line with constitution.

Using social analysis technique, this article provides a constitutional critique for returning the rights of the police in the context of civic education empowerment.

تحاول الدراسة الحالية استكشاف أبعاد السلوك الحيادي الذي يُفرض على أفراد الشرطة الإندو نيسية بحاه العملية الانتخابية، حيث يحرمون من الإدلاء بأصواتهم سواء في الانتخابات التشريعية أو التنفيذية. تدفع الدراسة بأن مثل هذه الحيادية، في أصلها، تعد تكبيالً لحق من الحقوق الأساسية للإنسان في إطار الدولة الديمقر اطية، وهو الأمر الذي يؤدي إلى تشويه الممارسة الديمقر اطية، ويبعلها تبدو متناقضة مع الدستور. وعبر الاستعانة مكنهجية تحليلية اجتماعية، تثمر المقالة الحالية رؤية نقدية، من وجهة نظر دستورية، من أجل إحياء حق الخيار السياسي لأفراد الشرطة الإندونيسية في إطار التمكين لعملية التربية القومية بشكل متسق.

Keywords: Kebijakan, Netralitas, Demokrasi, dan Pendidikan Kewarganegaraan 


\section{A. Pendahuluan}

Pemilihan umum merupakan pilar demokrasi yang secara hukum dan politis merupakan keniscayaan dalam negara modern. Namun, dalam penerapannya tidak semua unsur warga negara dapat menggunakan hak politiknya. Misalnya saja anggota TNI dan juga Polri termasuk warga negara yang dikecualikan dari hak politik tersebut. Hal ini dimaksudkan sebagai upaya memelihara dan menjaga sikap netralitas mereka dalam proses pemilihan umum, baik legislatif maupun pemilihan presiden. Mengawali kajian topik ini terlebih dulu perlu kita samakan persepsi terhadap makna yang terkandung dalam judul tulisan ini.

Pertama, topik ini memunculkan kata "hak pilih" secara harfiah meliputi "hak memilih" dan "hak dipilih". Sedang kata "Polri" menurut ketentuan Pasal 20 Ayat (1) Undang-undang Nomor 2 Tahun 2002 tentang Kepolisian Negara Republik Indonesia dinyatakan bahwa Pegawai Negeri Kepolisian Negara Republik Indonesia terdiri dari "Anggota Polri" dan "Pegawai Negeri Sipil (PNS)". Secara legal formal baik anggota Polri maupun Pegawai Negeri Sipil adalah warga negara yang memiliki status yang sederajat di depan hukum, sehingga semua warga negara memiliki hak yang sama dalam konteks politik.

Kedua, makna "Pemilu" merupakan wujud pesta dan penerapan asas demokrasi dalam kehidupan masyarakat dalam tata keberlanjutan struktur organisasi berbangsa dan bernegara guna memilih wakil rakyat di lembaga legislatif dan pasangan presiden/wakil presiden. Hak tersebut berlangsung untuk periode lima tahun ke depan dan dilakukan melalui mekanisme yang jujur, adil, langsung, umum, bebas, dan rahasia. Hal ini sebagaimana diatur dalam UU No. 10 Tahun 2008 tentang Pemilihan Umum anggota DPR, DPD, dan DPRD.

Untuk maksud di atas Polri diberikan peran, tugas, serta kewajiban sebagai unsur anggota pengawas, pengaman, dan pelaksana Pemilu. Untuk memenuhi tuntutan kerja, kepentingan, dan kemampuan tersebut Polri harus dapat berbuat, berkehendak, dan bekerja secara baik dan netral dalam keberadaan, peran, maupun tugasnya. Dalam wujud penampilannya Polri juga dituntut harus dapat memainkan peranan yang mandiri, proporsional, dan profesional.

Setidaknya, Polri dalam penegakan hukum dan netralitas dalam pemilu harus mempertimbangkan beberapa hal yang saling berkaitan. Pertama, konsep penegakan hukum bersifat total (total enforcement concept). Ini menuntut agar semuanya laik 
dipertimbangkan tanpa kecuali. Kedua, penegakan hukum bersifat penuh (full enforcement concept). Perlu disadari bahwa konsep total tersebut perlu dibatasi dengan hukum acara. Ketiga, konsep penegakan hukum aktual yang muncul setelah adanya diskresi dalam penegakan hukum. ${ }^{1}$

Selain itu, Polri sebagai salah satu pilar dalam kehidupan demokrasi tidak dapat menghindar dari persoalan negara dan kewarganegaraan. Hal ini sangat penting oleh karena Polri yang dituntut netralitas dan bekerja profesional diharuskan memahami aspek-aspek konstitusionalitas negara, institusi negara, fungsi pemerintahan, tujuan negara dan masyarakat sebagai warga negara. Sehingga, posisi sebagai warga negara dan juga sebagai aparat penegak hukum menjadi sangat tegas, terkait hak, kewajiban serta tanggung jawabnya. ${ }^{2}$

Terkait dengan peran netralitas Polri dalam Pemilu, maka timbulnya persoalan. Pertama, bagaimana netralitas Polri dalam teori dan praktek. Kedua, pemikiran prospektif netralitas Polri ke depan terkait dengan netralitas Polri sebagai institusi penegak hukum sekaligus anggotanya sebagai warga negara. Adapun argumentasi yang penting dikedepankan adalah netralitas Polri dalam pemilu penting dan diperlukan, tanpa harus menghilangkan hak-hak politik khususnya hak untuk dipilih untuk turut serta dalam pemerintahan dan kenegaraan.

Dalam tulisan ini diargumentasikan bahwa perlu diwujudkan pemulihan hak pilih Polri dalam penyelenggaraan pemilu tanpa menampik sikap netralitas profesionalitas dan proporsionalitas Polri sebagai upaya melakukan peningkatan kualitas dalam aspek pendidikan kewarganegaraan.

\section{B. Argumentasi Netralitas Polri dalam Pemilu}

Netralitas dapat diartikan sebagai suatu sikap tidak secara aktif dan pasif memberi dukungan pada kelompok/partai politik yang memiliki kepentingan dalam pemenangan pemilu. Dalam sejarah ketatanegaraan RI, sikap demikian ini disebut sebagai indepedensi Polri sebagai unsur dalam penegakan hukum. Pejabat Polri tidak boleh melakukan intervensi terhadap kasus yang ditangani bahawannya. Menurut Awaloedin Djamin, indepedensi atau kemandirian Polri

1 Pembahasan lebih komprehensif, baca Muladi dalam Satjipto Rahardjo, Membedab Hukum Progresif, (Jakarta: Penerbit Buku Kompas, 2007), hal. 212.

2 Kajian lebih lanjut dapat dibaca, Tim ICCE UIN Jakarta, Pendidikan Kewarganegaraan (Civil Education), Demokrasi, HAM dan Masyarakat Madani, (Jakarta: IAIN Press, 2000). 
diartikan mandiri operasional dan pembinaan. Selain itu, juga mandiri dalam arti cukup jumlah personil, kualitas profesionalisme, dan juga memperoleh kesejahteraan. $^{3}$

Atas dasar pandangan tersebut menjadi relevan untuk mengaitkan netralitas dengan sikap independensi Polri secara kelembagaan. Terdapat beberapa alasan atau argumentasi mengapa Polri perlu memiliki sikap netral terhadap Pemilu. Di satu pihak, cerminan netraltias Polri dalam Pemilu harus dapat diwujudkan pada kemandirian, proporsionalitas dan profesionalitas keberadaan dan pelaksanaan kerja Polri. Sebab, peran Polri merupakan "pengayom, pelindung, dan pelayan masyarakat, penegak hukum maupun pemelihara keamanan dan ketertiban masyarakat".

Di pihak lain, Polri dituntut dapat bergerak bebas dan mampu berada di tengahtengah kehidupan masyarakat. Sehingga, dalam penampilan sikap yang tidak berpihak kepada kepentingan golongan atau afiliasi dalam aktivitas politik praktis partai politik tertentu sangat menentukan. Mengingat tuntutan tugas dan kewajiban Polri itu perlu diperhatikan ada tidaknya sifat netralitas tersebut. Sikap netralitas ini merupakan tuntutan dan cerminan lembaga Polri sekaligus dapat menjadi model pendidikan warga negara yang lain.

Sikap netralitas Polri dalam Pemilu diargumentasikan sebagai berikut. Pertama, untuk memelihara, menjaga, dan mewujudkan profesionalitas dan proporsionalitas dalam kerja Polri secara perorangan maupun kelembagaan diperlukan kearifan dan kelegowoan dari berbagai pihak dalam Polri melakukan penundaan dan atau tidak menggunakan hak-hak politiknya (hak memilih) tanpa harus kehilangan hak asasinya sebagai anggota masyarakat, anak bangsa, maupun sebagai warga negara Indonesia untuk mendapatkan "hak dipilih". Sebab, dengan adanya hak memilih dan dipilih itu berarti warga negara ikut andil dalam menentukan kebijakan pemerintahan. ${ }^{4}$

Kedua, untuk mewujudkan peran dan tugas Polri dalam memberikan perlindungan, pengayoman, dan pelayanan kepada masyarakat, maupun dalam tugas penegakan hukum serta pembinaan kondisi keamanan dan ketertiban masyarakat, khususnya dalam mewujudkan visi, misi, dan strategi community policing atau "perpolisian masyarakat" diperlukan status dan perilaku kerja Polri yang independen, solid, dan dekat dengan masyarakat. Namun dengan jati dirinya tersebut ia seharusnya

Fajrul Falaakh dkk, Implikasi Reposisi TNI - Polri di Bidang Hukum, (Yogyakarta: FH UGM, 2001), hal. 172.

4 Tim ICCE UIN Jakarta, Pendidikan Kewarganegaraan..., hal. 78. 
tetap mempunyai kesempatan untuk menentukan hari depan masyarakat, bangsa, dan negaranya. Hal ini seiring dengan pendapat E. Adlow, Pakar Hukum Universitas Boston, yang menegaskan bahwa pekerjaan polisi adalah profesi rumit dalam peradaban yang kompleks, tak hanya mengurusi rampok tetapi semua aspek kehidupan masyarakat dan negara. ${ }^{5}$

Ketiga, Polri dapat ikut mewujudkan tujuan dan kepentingan nasional yang dinyatakan dalam pembangunan nasional dan penyelenggaraan Pemilu guna kelangsungan dan keberlanjutan kehidupan bermasyarakat, berbangsa, dan bernegara. Karena itu, diperlukan gugus tugas dan atau satuan fungsi kemampuan kerja dalam organisasi Polri yang harus dibentuk secara terencana, terstruktur dan tersistematis. Sehingga, hak kewajiban serta kewenangan dan tanggung jawab untuk kepentingan bangsa dan negara dapat dicapai secara bertahap, sesuai dengan garis organisasi. ${ }^{6}$

Keempat, untuk melaksanakan peran dan tugas Polri sebagai unsur pengamanan, pengawal, dan pengawas Pemilu diperlukan tampilan dan sikap Polri yang tegas, netral, dan berwibawa. Oleh karena itu, keberadaan dan sikap kerja Polri harus selalu tidak terikat dan tidak dipengaruhi oleh bermacam kepentingan golongan yang menjadi kontestan Pemilu. Tuntutan ini menjadi sangat logis karena Polri sebagai pengayom juga sebagai penegak hukum yang selalu dituntut sikap yang benar dan adil dalam melaksanakan tugasnya.

Kelima, untuk menghindari kondisi menipisnya rasa loyalitas, dedikasi, dan atau kinerja kepolisian dalam pelaksanaan tugas Polri, serta untuk menjaga kondisi terdegradasinya rasa kedisiplinan dan kepatuhan unit-unit satuan kerja Polri dalam melaksanakan peran serta tanggung jawab kerjanya. Dengan adanya berbagai tarikan dan kepentingan politik praktis dari partai-partai politik seperti yang pernah dialami masa lalu, maka diperlukan suatu ketegasan dan sikap arif dari setiap aparatur Polri untuk bersikap netral .

Keenam, untuk memenuhi, menjaga, dan mewujudkan harapan masyarakat agar Polri dapat menjadi benteng negara, pembina masyarakat, wasit kemurnian demokrasi dalam Pemilu, maupun agent of change dalam reformasi nasional, diperlukan komitmen, konsisten, dan kejujuran Polri dalam bertindak bebas dan berperilaku netral pada setiap tahapan proses Pemilu. Hal ini seiring dengan sikap penegakan hukum yang harus menjunjung tinggi etika dan moral. Sebab, dalam

5 Lihat tulisan Anton Tabah dalam harian Kedaulatan Rakyat, 9 November, 2000.

6 Teguh Sudarsono, Bianglala: Segantang Wacana dan Aktualisasi Kelangsungan Reformasi Polri Yang Berkelanjutan, (Jakarta: PT. Mulia Angkasa, 2007). 
perkembangan saat ini reformasi hukum juga seyogianya melakukan reformasi institusi penegak hukumnya. Konsekuensinya, Polri sebagai institusi penegak hukum yang memainkan peranan perubahan sepatutnya dituntut tidak saja berpikir legal formal atau pendekatan yuridis, melainkan perlu meningkatkan upaya untuk memahami rule of ethic atau aturan kode etik. ${ }^{7}$

Hal ini mengacu pada Deklarasi Universal Hak Asasi Manusia PBB tahun 1948 bahwa apa yang secara formal diproklamirkan pada level hak melalui perspektif etika sepenuhnya terhadap martabat pribadi manusia yang intrinsik, kebebasan yang tidak boleh dihilangkan dan kesejajaran mendasar semua orang serta solidaritas dan indepedensi semua manusia. ${ }^{8}$ Adapun tuntutan netralitas Polri secara legal formal, atau kerangka hukum normatif tampak diargumentasikan tidak saja untuk mencegah ketimpangan dalam penegakan hukum, utamanya juga untuk menolak timbulnya konflik kepentingan yang dapat merugikan masyarakat dan juga Polisi sebagai warga negara.

\section{Netralitas Polri Tanpa Menghilangkan Hak Pilih}

Sikap netralitas polri tersebut menjadi sangat penting terutama dikaitkan dengan dalih-dalih hukum yang menegasikan hak pilih dan hak dipilih bagi Polri. Tidak mengherankan bahwa netralitas polisi diperlukan, tanpa harus menghilangkan hakhak politiknya sebagai warga negara yang memiliki hak kesederajatan hukum mestinya harus menjadi bahan pertimbangan. Adapun beberapa alasan yang dapat digunakan sebagai dalil hukum antara lain sebagai berikut.

Pertama, hak memilih sesungguhnya tidak tergolong pada hak dasar yang tidak dapat dikurangi atau hak absolut. Hal ini sesuai dengan pasal 4 Ayat (2) International Covenant on Civil and Political Rights (ICCPR) yang telah diratifikasi oleh Undangundang Nomor 12 Tahun 2005 tentang Pengesahan Kovenan Internasional tentang Hak-hak Sipil dan Politik, yang menyatakan bahwa: "Walaupun dalam Pemilu hak memilih merupakan salah satu bentuk hak asasi manusia, namun hak tersebut bukan merupakan underogable rights". Karena itu, seseorang menggunakan hak pilih atau tidak menggunakan tidak menimbulkan konsekuensi hukum. Akan tetapi secara sosiologis dan politis sebenarnya kehilangan kontribusi dalam kaitannya dengan penentuan kebijakan dan keputusan penting lainnya untuk pencapaian tujuan negara.

7 Baca lebih lanjut, Djimly Asshiddiqie, Menuju Negara Hukum Yang Demokratis, (Jakarta: Sekjen Mahkamah Konstitusi, 2008).

8 Satjipto Raharjo, Membedah Hukum Progresif..., hal. 201. 
Kedua, bilamana norma hukum di atas dikaitkan pada penerapan faktualnya, maka akan ditemukan suatu indikator menarik. Hasil pengamatan selama ini ditemukan bahwa penggunaan hak memilih Polri dalam Pemilu telah dijadikan peluang bagi masuknya intrik dan kepentingan golongan yang menimbulkan gejolak masa dalam aktivitas politik praktis, sehingga menjadi sumber konflik dan keretakan soliditas internal Polri sendiri. Penetapan hak memilih dapat menimbulkan situasi kontraproduktif.

Karena itu, agar konflik tersebut tidak berkembang menjadi conflict of interest, Polri harus dijauhkan dari segala tarikan kepentingan golongan maupun aktivitas politik praktis dari partai politik peserta pemilu. Ross Cranston ${ }^{9}$ menegaskan bahwa upaya untuk mencegah timbulnya konflik kepentingan harus didekati dengan tiga cara, yaitu pentingnya keterbukaan (disclosure), pengaturan yang jelas dan pasti (regulation), dan keterbatasan terhadap usaha-usaha yang berbau bisnis. Hal ini juga harus diperkuat dengan adanya kode etika yang diterapkan. Misalnya, polisi tidak dibenarkan masuk untuk menjadi anggota salah satu partai politik atau organisasi sosial lain yang dapat mengganggu sikap netralitas. Namun dalam kondisi kesejateraan Polri yang masih relatif belum sejahtera, mustahil mereka dapat memegang teguh amanat dan kemandirian tersebut. Karena itu, diperlukan kebijakan yang mendorong polisi terpenuhi kebutuhan mendasar secara sosial ekonomi, pendidikan, dan kesehatan mengingat aspek penting kehidupan bernegara dan bermasyarakat adalah terciptanya kesejahteraan dan kemakmuran masyarakat.

Ketiga, sehubungan dengan tantangan tugas Polri yang semakin kompleks, secara faktual perlu diminimalisasi berbagai kondisi yang dapat menimbulkan perbedaan dan atau keretakan dalam intern Polri. Adanya keterikatan paham golongan maupun kepentingan tertentu di luar lingkup kerja dan jati diri Polri dapat menimbulkan kondisi, baik secara langsung maupun tidak langsung, memecahkan soliditas kemampuan, konsentrasi kerja, maupun target dan hasil kerja Polri. Hal ini dapat mengganggu keutuhan peran polri sebagai pelindung, pengayom, dan pelayan masyarakat. Jelaslah, netralitas Polri menjadi sangat penting bilamana tidak ikut terlibat secara langsung dalam parpol.

Keempat, jika dibandingkan dengan jumlah penduduk Indonesia, maka suara Polri sebenarnya tidak terlalu signifikan. Jumlah Polri pada tahun 2009 yang tercatat hanya sejumlah 389.004 orang (terdiri dari 379.904 anggota Polri aktif dan 23.359 anggota personil PNS) dinilai tidak signifikan untuk mendongkrak perolehan suara dari partai politik. Di samping itu, penggunaan hak memilih Polri melalui partai politik dipastikan tidak akan memberi manfaat besar bagi Polri secara kelembagaan. Namun terhadap penundaan atau pengesampingan hak memilih Polri pada proses 
pemilu perlu adanya pemikiran secara cermat dan matang agar tidak menimbulkan polemik di kemudian hari.

Kelima, untuk menjaga objektivitas, efektivitas, dan optimalitas Polri dalam kinerja maupun hasil kerjanya perlu dilakukan penataan dan dikembangkan suatu sikap dan netralitas Polri yang dapat membangun dan membina kemampuan dalam kiprahnya. Sehingga, keberadaan Polri dapat memberi kontribusi positif baik bagi upaya mewujudkan dan menegakkan kepentingan nasional, agenda nasional, maupun pembangunan nasional sesuai harkat dan jati dirinya. Dengan kata lain, sikap netralitas mustahil dapat memberi imbas positif terhadap kinerja profesionanalitas polri, tanpa diimbangi dengan promosi pengembangan SDM yang berkualitas melalui jenjang pendidikan dan pelatihan yang terkait dengan keilmuan dan pengalaman. ${ }^{10}$

Keenam, Polri masih harus belajar banyak bila harus berkiprah dalam kancah politik praktis, terlebih lagi dengan besarnya tarikan kepentingan dari berbagai pihak yang dapat menyeret para personil Polri dalam kondisi conflict of interest. Hal ini dapat dipahami oleh karena meruyaknya politik otonomi dalam medan politik praktis yang selalu mengarah pada sistem parokial memungkinkan Polri dapat terkooptasi dalam sikap pemihakan. Untuk mencegah situasi tersebut dan menyesuaikan kondisi yang harmonis diperlukan suatu reformasi kebijakan publik terkait dengan eksistensi Polri.

Reformasi kebijakan publik Polri dapat dimaknai sebagai suatu kewenangan dari pemerintah, khususnya Polri yang dituangkan dalam peraturan hukum dengan tujuan menyerap dinamika masyarakat yang akan dijadikan acuan pengambilan keputusan agar terdapat tata hubungan sosial yang harmonis. ${ }^{11}$

Dengan demikian, sikap netralitas Polri terhadap Pemilu dan Pilpres sangat diperlukan dalam konstelasi demokrasi Indonesia. Namun sikap netralitas tersebut dapat dibangun manakala terpenuhi syarat adanya transparansi pengaturan yang jelas dan berkeadilan serta kode etik untuk tidak terlibat dalam bisnis dan juga terjaminnya kehidupan Polri yang makmur dan sejahtera.

9 Perhatikan karya Ross Cranston, Law Government and Public Policy, (Melbourne: Oxford University Press, 1987), hal. 101.

10 Hubungan antara Polri dan pembangunan nasional dapat dilihat dalam karya Lalu Mara Satria Wangsa, Merebut Hati Rakyat Melalui Nasionalisme, Demokrasi, dan Pembangunan, (Jakarta: Prima Media Pustaka, 2004), hal. 116.

11 Pentingnya reformasi lembaga negara termasuk Polri, lihat Chaizi Nasucha, Reformasi Administrasi Publik, (Jakarta: Grasindo, 2004), hal. 37. 


\section{Fakta Netralitas Dalam Pendidikan Kewarganegaraan}

Pada dasarnya penundaan dan atau pengesampingan hak memilih Polri dalam Pemilu secara normatif memang tidak dilarang. Dalam Hukum Internasional, yaitu menurut International Convention on Cultural and Political Rights, dengan tegas dinyatakan bahwa hak memilih dan hak pilih bukan merupakan larangan atau kewajiban yang mengikat. Sehingga, tak dipergunakan sama sekali pun tidak ada konsekuensi hukum.

Konsep HAM dalam bidang pendidikan tercermin dalam Mukadimmah UUD 1945 yang menyebutkan bahwa pemerintah Indonesia bertugas untuk mencerdaskan kehidupan bangsa. Dalam Orde Reformasi, pendidikan politik dan kewarganegaraan menjadi bagian penting, termasuk pendidikan dan hak-hak warga negara. ${ }^{12}$ Polisi sebagai penegak hukum sekaligus warga negara dapat mengekspresikan kebebasan berpendapat dan juga perbuatan yang baik sebagai teladan bagi keluarga, tetangga, dan juga kesatuan anggota Polri.

Namun dengan tidak digunakannya hak memilih Polri tersebut hendaknya perlu menjadi perhatian semua pihak mengingat penjabaran atas hak pilih merupakan bentuk pelanggaran Hak Asasi Manusia walaupun tidak sebagai underogable right. Sebagai sumbangsih Polri dalam kontribusinya untuk mewujudkan netralitas dan sebagai wujud profesionalitas, proporsionalitas, serta objektivitas Polri dalam mengawal proses dan jalannya Pemilu, perlu ditingkatkan tanpa harus mengabaikan hak pilih sebagai hak warga negara.

Sebab, situasi itu bertentangan ketika PNS memiliki hak pilih misalnya, Pegawai Negeri Sipil (PNS) yang bekerja di unit-unit kerja Kepolisian Negara Republik Indonesia. Walaupun peran dan keberadaannya sudah berubah dari wujud supplement menjadi compliment kerja Polri berdasarkan Undang-undang Nomor 2 Tahun 2002 tentang Polri pada Pasal 20 Ayat (2) menentukan bahwa: "terhadap Pegawai Negri Sipil berlaku ketentuan peraturan perundang-undangan di bidang kepegawaian. Mereka tetap menggunakan hak memilih dalam Pemilu seperti halnya Pegawai Negeri Sipil lainnya.

Situasi ketidaksamaan hak ini akan menimbulkan kecemburuan yang berakhir dengan adanya perlakuan yang tidak adil. Sebab, pembedaan hak pilih dan hak dipilih dalam satu instansi Polri tampak jelas bertentangan dengan hak perlakuan

12 Lihat lebih lengkap, Bagir Manan, Perkembangan Pemikiran dan Pengaturan Hak Asasi Manusia di Indonesia, (Bandung: YHDS, 2001). 
dan penggolongan PNS dan non-PNS yang sama di depan hukum sebagai hak dasar diatur dalam Pasal 27 UUD 1945. Terkait dengan prinsip kesetaraan di depan hukum maka konsep demokrasilah yang memberi landasan dan mekanisme kekuasaan berdasarkan prinsip kesamaan dan kesederajatan manusia sehingga baik warga negara biasa, Politisi, TNI, mestinya mendapatkan hak yang sama sebagai warga negara. Demokrasi menempatkan manusia sebagai pemilik kedaulatan yang kemudian dikenal dengan prinsip kedaulatan rakyat.

Untuk memenuhi hak-hak tiap manusia tidak mungkin dicapai oleh masingmasing orang secara individual tetapi harus bersama-sama. Itulah sebagai perjanjian masyarakat (contract social). Menjadi sangat penting agar maksud dan tujuan negara, yaitu terjaminnya hak-hak asasi manusia dalam suatu hukum dasar, bisa tercapai.

Argumentasi lain juga menyebutkan atas adanya kesepakatan para anggota Polri untuk menunda atau belum menggunakan hak memilih dalam Pemilu tentunya tidak berarti Polri harus kehilangan hak dipilih, sehingga peluang untuk menjadi pejabat penyelenggara pemerintahan dalam lembaga legislatif tidak tertutup sama sekali. Dengan kata lain, norma hukum tentang netralitas Polri dalam pemilu tidak berarti anggota Polri harus kehilangan hak politik secara keseluruhan. Sekiranya anggota Polri dihadapkan pada adanya larangan memilih maka hak untuk dipilih mestinya harus dijamin oleh undang-undang.

Sebagai perbandingan, kedudukan dan peran Polisi dalam legislatif bukan hal yang aneh. Kepolisian adalah aparatur negara penegak hukum yang paling depan. Dalam konteks ini, polisi, hukum, dan undang-undang berada dalam satu ikatan sistem. Sebab menurut teori J.J. Rosseau, polisi adalah pemaksa masyarakat agar patuh pada undang-undang, sehingga keamanan dan ketertiban terpelihara. Sebagai pemaksa hukum kepolisian harus terlibat langsung sejak proses awal undang-undang itu dibuat badan legislatif. Misalnya, di beberapa negara bagian Amerika ada wakil kepolisian yang duduk di badan legislatif. Hal ini juga terjadi di Inggris di mana kepolisian terlibat dalam proses pembuatan undang-undang. ${ }^{13}$

Hal tersebut sesuai dengan ketentuan Pasal 21 Deklarasi Umum PBB Tahun 1948 tentang Human Rights dinyatakan: "Setiap orang berhak turut serta dalam pemerintahan negaranya secara langsung dan atau menjadi perwakilan di lembagalembaga legislatifnya melalui pemilihan secara bebas." Secara konsisten juga termuat dalam Konstitusi Undang-Undang Dasar Republik Indonesia Tahun 1945, pada

13 Lihat tulisan Anton Tabah dalam harian Kedaulatan Rakyat, 9 November, 2000. 
Bab X Pasal 27 Ayat (1) juga menyatakan: "Segala warga negara bersamaan kedudukannya di dalam hukum dan pemerintahan, dan wajib menjunjung hukum dan pemerintahan dengan tidak ada kecualinya."

Secara lebih lanjut ditegaskan dalam ICCPR yang telah diratifikasi oleh Undangundang Nomor 12 Tahun 2005 tentang Hak-hak Sipil dan Politik berikut: "Setiap warga negara mempunyai hak dan kesempatan yang sama untuk dan dalam penyelenggaraan negara maupun perwakilan di lembaga-lembaga legislatif tanpa pembedaan maupun pembatasan yang tidak wajar."

Bahkan dalam Pasal 10 Ayat (2) TAP MPR-RI Nomor VII Tahun 2000 dinyatakan: "Anggota Polri memang tidak menggunakan hak memilih dan dipilihnya, namun dalam penyelenggaraan negara dan ikut menentukan arah kebijakan nasional disalurkan melalui MPR paling lama sampai dengan 2009”. Sekiranya TAP MPR tersebut dipergunakan sebagai dasar pelarangan, maka tentu saja dapat dipandang sebagai kekhususan yang tidak sekaligus dapat diterapkan.

Keberadaan Polri dalam sistem pendidikan nasional memili peran dan fungsi eksekutif yang berkaitan dengan otonomi daerah. Jumlah anggota Polri, yaitu 389.004 jiwa, memiliki dampak positif dalam mendorong timbulnya kesadaran hukum masyarakat. Penyebarluasan anggota-anggota Polri di Kapolda, Kapolres, dan Kapolsek, di tingkat daerah akan semakin mendorong pendidikan hukum masyarakat. Pertama, para Kapolres dipersiapkan agar dapat mengantisipasi peran dan hubungan kepala daerah dan DPRD dalam semangat otonomi daerah. Selain itu, Polres dan Polsek harus mengenal daerah dan masyarakat secara baik, terutama Tamtama dan Bintara seyogianya diarahkan agar diambil dari daerah yang bersangkutan. Terakhir, aspek pendidikan kewarganegaraan dan hakhak politik memilih dan dipilih terkait dengan peran polri dalam menata hubungan dengan semua bentuk keamanan swakarsa, seperti Satpam, Hansip, Kamra, Satpol PP dan PPNS. Hal ini sesuai dengan UU No. 28 Tahun 1997 bahwa Polri memberi pembinaan teknis, mengkoordinasi dan mengawasi Polsus, PPNS, dan bentuk keamanan swakarsa. ${ }^{14}$

Anggota Polri dalam keberadaannya juga berstatus sebagai warga negara Indonesia yang mempunyai hak dan kesempatan untuk ikut aktif baik dalam penyelenggaraan negara maupu penentuan kebijakan nasional melalui lembagalembaga eksekutif dan legislatif. Sehingga, netralitas yang mengorbankan hak-hak politik dan kurangnya jaminan kesejahteraan sosial ekonomi cenderung tidak memiliki hubungan korelasi yang positif dalam implementasinya.

14 Fajrul Falaakh dkk, Implikasi Reposisi TNI..., hal. 181. 


\section{E. Penutup}

Hak Pilih Polri dalam pemilu dengan alasan untuk memenuhi tuntutan objektivitas, profesionalitas, dan netralitas sangat penting dan diperlukan dalam pelaksanaan tugasnya dan guna mewujudkan kepentingan nasional serta agenda nasional. Namun, tidak berarti bahwa Polri harus kehilangan hak dipilih dalam penyelenggaraan pemerintahan.

Jika pelarangan mutlak ini dilakukan dalam suatu kondisi kesengajaan yang terstrukturisasi dalam suatu aksi, penormaan, akan tampak sebagai pelanggaran terhadap Hak Asasi Manusia. Karena itu, upaya-upaya dan sikap serta prakarsa yang jelas perlu disuarakan agar salah satu hak politik bagi anggota Polri diberi jaminan yang tegas secara konstitusional sebagai warga negara. Sebab, jika pembiaran hakhak politik ini di lembagakan di kalangan Polri, tidak mengherankan berdampak negatif pada kualitas pendidikan kewarganegaraan sebagai akibat dari pembiaran atas kedudukan yang tidak sejajar dalam hukum.

Untuk menampung dan memfasilitasi hak dipilih bagi anggota Polri dalam pesta demokrasi (Pemilu, Pilkada, dan Pilpres), khususnya guna mewadahi bentuk kreativitas, wujud inovasi, serta aktivitas perjuangan Polri dalam mewujudkan kelangsungan dan keberlanjutan tata kehidupan bermasyarakat, berbangsa, dan bernegara, Polri seyogianya diberi toleransi untuk menyiapkan mekanisme dan atau saluran khusus guna melakukan proses pemilihan yang berbeda.

Sikap netralitas Polri dalam Pemilu legislatif dan Pilpres sangat dituntut keberadaannya tanpa harus menghilangkan hak-hak pilih dan dipilih. Aspek pendidikan kewarganegaraan dalam konteks ini tampak jelas. Tidak dapat dijadikan jaminan dalam melaksanakan tugas secara profesional, termasuk dalam penegakan hukum, terlebih lagi telah menimbulkan pelanggran terhadap asas kesederajatan hukum (inequality before the law). Fungsi dan peran polri dalam sistem pendidikan kewarganegaraan, akan memberi kontribusi yang signifikan dalam peningkatan kesadaran hukum masyarakat, mengingat peran Polri tak hanya dapat mendukung kesadaran hukum masyarakat dalam proses legislasi di DPR/DPRD dan Pemda, tapi juga melakukan koordinasi antar aparat keamanan tingkat kabupaten, kecamatan dalam penciptaan rasa aman dan tertib masyarakat di berbagai lapisan.

Karena itu, agar netralitas Polri dapat dikembangkan, perlu suatu reformasi kebijakan di tubuh Polri, dengan berupaya meningkatkan kualitas SDM Polri melalui pendidikan dan jaminan kesejahteraan yang semakin meningkat tanpa mengurangi hak-hak politik mereka. 


\section{DAFTAR PUSTAKA}

Ambrose, Stephen E. 2003. Tentara Sukarela. Terj. A. Rachman Zainuddin. Jakarta: Yayasan Obor Indonesia.

Asshidiqie, Djimly. 2008. Menuju Negara Hukum Yang Demokratis. Jakarta: Sekjen Mahkamah Konstitusi.

Blumenson, Martin and Stokesbury, James L. 2000. Para Pakar Seni Komando. Terj. Dadi Pakar. Bandung: Percetakan Angkasa.

Cranston, Ross. 1987. Law Government and Public Policy. Melbourne: Oxford University Press.

Falakh, Fajrul. 2001. Implikasi Reposisi TNI-Polri di Bidang Hukum. Yogyakarta: FH UGM.

Huntington, Samuel P. 2003. Prajurit dan Negara: Teori dan Politik Hubungan Militer - Sipil. Jakarta: Grasindo.

Majone, Giandomenico. 1992. Deregulation or Re-regulation Regulatory Reform in Europe and the United States. London: Pinfer Publisher.

Manan, Bagir. 2001. Perkembangan Pemikiran Dan Pengaturan Hak Asasi Manusia di Indonesia. Bandung:YHDS.

Raharjo, Satjipto. 2007. Membedah Hukum Progresif. Jakarta: Penerbit Buku Kompas. Nasucha, Chaizi. 2004. Reformasi Administrasi Publik. Jakarta: Grasindo.

Soedarsono, Teguh. 2007. Bianglala: Segantang Wacana dan Aktualisasi Kelangsungan Reformasi Polri yang Berkelanjutan. Jakarta: Mulia Angkasa.

Tabah, Anto. 2000. Kedaulatan Rakyat, 9 November.

Wangsa, Lalu Mara Satria. 2004. Merebut Hati Rakyat Melalui Nasionalisme, Demokrasi, dan Pembangunan. Jakarat: Primamedia Pustaka.

Tim ICCE UIN Jakarta. 2000. Pendidikan Kewarganegaraan (Civil Education), Demokrasi, HAM dan Masyarakat Madani. Jakarta: IAIN Jakarta Press.

Ketetapan MPR-RI Nomor VI/MPR/2000 tentang Pemisahan TNI dan Polri.

Ketetapan MPR-RI Nomor VII/MPR/2000 tentang Peran TNI dan Peran Polri

Undang-Undang Dasar Republik Indonesia Tahun 1995. 
Undang - undang Republik Indonesia Nomor 2 Tahun 2002 tentang Kepolisian Negara Republik Indonesia.

Undang-undang Republik Indonesia Nomor 39 Tahun 1999 tentang Hak Asasi Manusia.

Buku Saku Polri. 2007. Pengenalan Prinsip-prinsip Dasar Hak Asasi Manusia Bagi Penegak Hukum. Jakarta: Polri. 